\title{
Non-Responsiveness to Hepatitis-B Vaccination: Revaccination and Immunogenetic Typing
}

\author{
A. Krämer ${ }^{1}$, D. Herth ${ }^{1}$, H.-J. von Keyserlingk ${ }^{2}$, W.-D. Ludwig ${ }^{2}$, H. Hampl ${ }^{3}$, D. Sommer ${ }^{1}$, \\ E.G. Hahn ${ }^{1}$, and E.-O. Riecken ${ }^{1}$ \\ ${ }^{1}$ Medizinische Klinik und Poliklinik, Schwerpunkt Gastroenterologie \\ ${ }^{2}$ Medizinische Klinik und Poliklinik, Schwerpunkt Hämatologie und Onkologie \\ ${ }^{3}$ Institut für Klinische und Experimentelle Virologie Klinikum Steglitz, Freie Universität Berlin
}

Summary. The variation in immune responses to standard inoculation of the hepatitis-B virus vaccine suggest that host factors influence response in ways that are not presently understood. We studied 25 low/nonresponding health care workers (anti-HBs titer $<50 \mathrm{IU} / 1$ ) after the third inoculation of an experimental hepatitis- $B$ vaccine to determine their immune status (through lymphocyte phenotypes) and HLA type. After application of a fourth inoculation, the seroconverting subjects showed only low anti-HBs levels; three male subjects remained anti-HBs negative. Twelve months after the fourth inoculation only 9 of 25 subjects $(36 \%)$ maintained anti-HBs titer $>10 \mathrm{IU} / 1$. Almost all subjects had normal B-cell and CD-4 and CD-8 counts and ratios. Relative to other European populations HLA-A-10 $(P<0.05)$, B-12 $(P<$ $0.025), \mathrm{CW}-5(P<0.05)$, DR-3 $(P<0.025)$, and DR-5 $(P<0.025)$ were increased, whereas DR-2 $(P<0.05)$ was decreased. However, after correction of the $P$-values for the number of HLA antigens determined, these differences were no longer significant. Furthermore, these HLA types were not the same as those reported in other studies (except for DR-3). We suggest that larger sample sizes or even not yet available immunogenetic markers will be required to prove an "immunogenetic background" in low/nonresponders, if it exists.

Key words: Genetics - Hepatitis-B virus - Immunogenetics - Vaccination

HBV infection with its complications - fulminant course, chronicity, and development of hepatocel-

Abbreviations : anti-HBc $=$ antibody to hepatitis- $\mathrm{B}$ core antigen; anti-HBs = antibody to hepatitis-B surface antigen; $\mathrm{HBsAg}=$ hepatitis-B surface antigen lular carcinoma - remains a major public health problem even in areas of low prevalence, such as Europe and the United States. To minimize this risk, HBV vaccination has been recommended for groups at high risk, such as health care workers. However, the $3 \%-5 \%$ of healthy persons who fail to respond to active immunization against $\mathrm{HBV}$ infection offer a challenge for research $[6,24]$.

The lack of immune response to $\mathrm{HBs} \mathrm{Ag}$ may be related to genetic factors, since female vaccine recipients usually develop higher antibody levels against HBsAg than do males [13]. On the other hand, the immune defect of hemodialysis patients and other immunocompromised patients may be a more general one, causing seronegative rates of up to $40 \%[3,7,22,10]$.

Is there an "immunogenetic background" for nonresponsiveness in active immunization against hepatitis-B virus (HBV) infection?

Better understanding of the immune response regulation towards a complex peptide antigen (HBsAg) in man may provide new strategies for the preparation of a synthetic vaccine that circumvents nonresponsiveness.

\section{Methods}

\section{Participants}

Between October 1982 and July 1983, 217 health care workers were inoculated three times with an experimental hepatitis- $B$ vaccine. The vaccination schedule was: first inoculation at 0 , second inoculation at 1 month after the first inoculation, and third inoculation 5 months after the first inoculation. Each subject was given a total of $120 \mu \mathrm{g}$ HBsAG in the deltoid region. All participants denied prior hepatitis, were serologically negative for HBsAg, anti-HBs, and/or anti-HBc prior to first inoculation and all had normal transaminase levels. 
Four percent of the test subjects (6 males and 3 females) did not seroconvert, i.e., they developed anti-HBs titers below $3 \mathrm{IU} / 1$ (nonresponders). Fourteen percent of the subjects (22 males and 9 females) developed anti-HBs titers above 3 IU $/ 1$ and below $50 \mathrm{IU} / 1$ (low responders). The immune response showed a definite dependence on the sex and age of the vaccinated subjects. Males and older persons produced significantly lower anti-HBs titers. These data have been published previously [13].

Of the 40 subjects with anti-HBs titers below $50 \mathrm{IU} / 1$ after the third inoculation, 25 (6 nonresponders, 4 male and 2 female; and 19 low responders, 13 male and 6 female) were located 1 year later and are the subjects of this report. The median age of the 17 males was 36 years (range, $30-53$ years), and the median age of the 8 females was 31 years (range, 23-46 years). A comparison of different characteristics revealed that the low/ nonresponders consisted of significantly more males than the responders $(P=0.046$, Fisher's Exact Test, two-tailed).

\section{Revaccination and Anti-HBs Titer}

These 25 low/nonresponders were revaccinated a fourth time with the same experimental hepatitis-B vaccine $(40 \mu \mathrm{g} \mathrm{HBs} \mathrm{Ag}$ per dose) intramuscularly in the deltoid region approximately 1 year after the third inoculation. At 3 weeks and at 1 year after the fourth inoculation, sera were obtained for anti-HBs titers, as determined by radioimmunoassay (AUSAB, Abbott Laboratories, North Chicago, Ill.). International units per liter were calculated according to the formulas developed by Hollinger [9].

\section{Immunologic and Genetic Methods}

B lymphocytes and $\mathrm{T}_{3^{-}}, \mathrm{T}_{4^{-}}$, and $\mathrm{T}_{8}$-lymphocyte populations were determined as has been previously described [8]. From these data, $\mathrm{T}_{4} / \mathrm{T}_{8}$ ratios were calculated.

HLA-A, -B, -C, and -DR antigens were determined by the standard two-step microlymphocytotoxicity test according to Terasaki and McClelland [25] using the modification by van Rood [26]. A comparison was made with the results on more than 2500 Europeans [12] whose distribution of HLA antigens was very similar to that of healthy blood donors tested at this hospital.

\section{Statistics}

Statistical assessment of the frequency of HLAantigens was done using the chi-square test and
Yate's correction [1]. Adjustment of the $P$-values was done according to Svejgaard, which involved multiplying the $P$-values by the number of antigens tested [23].

\section{Results}

\section{Revaccination}

Three weeks after the fourth inoculation, three male participants $(12 \%)$ had not produced an antiHBs titer above $3 \mathrm{IU} / 1$. The remaining $22(88 \%)$ showed titers between 3.6 and $1231 \mathrm{IU} / 1$ (Fig. 1). Twelve months after the fourth inoculation the titer of anti-HBs had declined markedly (Fig. 2).

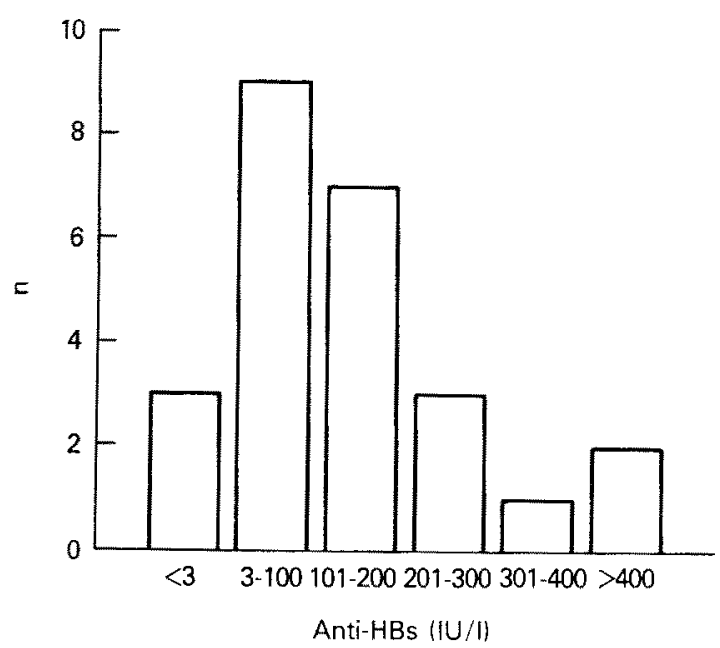

Fig. 1. Distribution of anti-HBs titers 3 weeks after the fourth inoculation. Note the relatively low anti-HBs levels. Three male participants still remained nonresponders (anti-HBs titers $<3 \mathrm{IU} / 1)$. The highest titer was $1231 \mathrm{IU} / \mathrm{m}, n=$ number

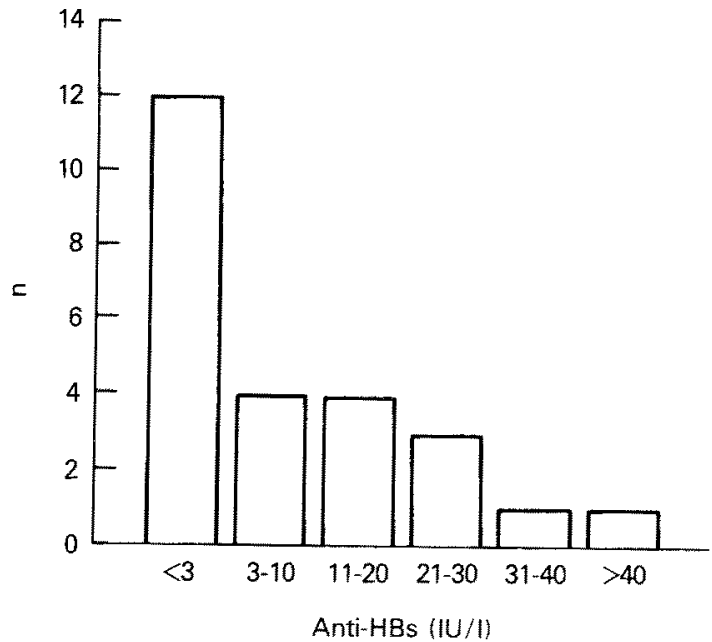

Fig. 2. Distribution of anti-HBs titers 12 months after the fourth inoculation. Note the marked titer decline. Sixteen participants had anti-HBs titers $\leq 10 \mathrm{IU} / 1 ; n=$ number 
Table 1. HLA-DR frequencies of the low/nonresponders. DR3 and DR5 were found to be increased, whereas DR2 was decreased. Note, however, that significance did not hold up after the $P$-values were corrected by the number of determined HLA antigens $\left(\mathrm{cp}^{*}=\right.$ corrected $P$ ). Controls were taken from a European population analysis [12]; OR, odds ratio; n.s., not significant

\begin{tabular}{|c|c|c|c|c|c|c|c|}
\hline \multirow[t]{2}{*}{ Antigen } & \multicolumn{2}{|c|}{ Low/nonresponders $(n=25)$} & \multicolumn{2}{|c|}{ Controls $(n=2499)$} & \multirow{2}{*}{$\begin{array}{c}\text { OR } \\
\text { OR }\end{array}$} & \multirow{2}{*}{$\begin{array}{l}P \\
p\end{array}$} & \multirow{2}{*}{$\begin{array}{l}\mathrm{cp} * \\
\mathrm{cp} *\end{array}$} \\
\hline & $N$ & $\%$ & $n$ & $\%$ & & & \\
\hline DR1 & 4 & 16.7 & 332 & 13.3 & 1.30 & $>0.05$ & n.s. \\
\hline DR2 & 2 & 8.3 & 627 & 25.1 & 0.27 & $<0.05$ & $<2.35$ \\
\hline DR3 & 10 & 41.7 & 509 & 20.4 & 2.80 & $<0.025$ & $<1.8$ \\
\hline DR4 & 6 & 25.0 & 457 & 18.3 & 1.49 & $>0.05$ & n.s. \\
\hline DR5 & 10 & 41.7 & 487 & 19.5 & 2.95 & $<0.025$ & $<1.8$ \\
\hline DRw6 & 1 & 4.2 & 107 & 4.3 & 0.97 & $>0.05$ & n.s. \\
\hline DR7 & 5 & 20.8 & 584 & 23.4 & 0.86 & $>0.05$ & n.s. \\
\hline DRw8 & 1 & 4.2 & 135 & 5.4 & 0.76 & $>0.05$ & n.s. \\
\hline DRw9 & 1 & 4.2 & 55 & 2.2 & 1.93 & $>0.05$ & n.s. \\
\hline DRw10 & 0 & 0 & 35 & 1.4 & & $>0.05$ & n.s. \\
\hline
\end{tabular}

Twelve subjects ( $48 \%$ ) were now anti-HBs negative (anti-HBs less than 3 IU/1). Sixteen subjects (64\%) showed anti-HBs titers $\leq 10 \mathrm{IU} / 1$, which is felt to be the minimum effective titer against hepatitis- $B$ virus infection. The anti-HBs titer of 8 other participants $(32 \%)$ ranged from $11 \mathrm{IU} / 1$ to $40 \mathrm{IU} / 1$. Only 1 subject showed a markedly high antibody titer of $155 \mathrm{IU} / \mathrm{l}$. No subject with anti-HBs titers of $\geq 200$ IU/1 3 weeks after the fourth inoculation decreased to $<10 \mathrm{IU} / 1$ during the 12 months after that inoculation.

\section{Immunologic Studies}

Most subjects had normal $\mathrm{T}_{3}$ - (median 1260, range $470-3270 / \mathrm{mm}^{3}$ ), $\quad \mathrm{T}_{4^{-}}$(median 770 , range $188-2240 / \mathrm{mm}^{3}$ ), and $\mathrm{T}_{8}$-lymphocyte (median 376 , range $120-1470 / \mathrm{mm}^{3}$ ) counts. Only 1 subject had a low $\mathrm{T}_{4}$-cell count $\left(188 \mathrm{cells} / \mathrm{mm}^{3}\right)$. The $\mathrm{T}_{4} / \mathrm{T}_{8}$ ratio was $<1$ in this and in another subject who had an increased $\mathrm{T}_{8}$-cell count $\left(1470 / \mathrm{mm}^{3}\right)$. Since antibody synthesis requires $\mathrm{B}$ cells, we also determined these quantitatively (median 175, range $42-590 / \mathrm{mm}^{3}$ ). Only 1 subject, different from the above-mentioned ones, showed a reduced B-cell count (only $42 / \mathrm{mm}^{3}$ ). Neither difference was statistically significant. Clinically and serologically, there was no evidence of acute or chronic infection, nor of a general immunodeficiency in these subjects.

\section{Histocompatibility Testing}

The 25 participants were examined for their HLA$A,-B$, and $-C$ antigens and 24 were examined for HLA-DR antigens. The DR typing was not successful in 1 subject. For controls, we used the data from a European population analysis in which more than 2500 European sera were typed [12].

A-10 $(P<0.05)$, B-12 $(P<0.025)$, and CW-5 $(P<0.05)$ were found to be increased. DR-2 expression was decreased $(P<0.05)$ and DR-3 $(P<$ $0.025)$ and DR-5 $(P<0.025)$ were increased (Table 1). However, the $P$-values were no longer significant after correction for the number of HLA antigens determined.

\section{Discussion}

Hepatitis-B vaccine is made of purified $\mathrm{HBsAg}$ prepared from the plasma of chronic HBsAg carriers. Several factors are known to be associated with diminished antibody responsiveness to vaccination. The immune response is usually excellent in females and young recipients, but decreases with age. Males evidence significantly lower anti-HBs levels than females $[13,28]$. Hemodialysis and immunosuppression negatively affect immune response to vaccination $[3,7,22,10]$.

We administered a fourth inoculation to 25 health care workers who had no or only a minor immune response after three inoculations. Three subjects failed to respond at all to the fourth inoculation. Only 9 persons (36\%) remained protected ( $>10 \mathrm{IU} / 1$ anti-HBs) 12 months after the fourth inoculation. Similar findings among poor responders were also reported by Craven and coworkers using a different vaccine preparation [5]. On the other hand, among normal responders only $8.7 \%$ fell to unprotective levels over 12 months [11]. Generally, levels of anti-HBs following immunization predict levels 12 months later.

There were no significant changes of total lymphocytes and lymphocyte subpopulatons. Thus, 
the immune defect in the low/nonresponders seems to be specific for HBsAg and does not indicate a general immunodeficiency.

Patients with chronic hepatitis-B virus infection are known to be hyporesponsive to HBsAg, as were these study participants. The low response has been attributed to decreased $\mathrm{T}_{4} / \mathrm{T}_{8}$-lymphocyte ratios due to elevated $T_{8}$-lymphocyte cell counts in chronic hepatitis- $\mathrm{B}$. Activation of $\mathrm{T}_{8}$ lymphocytes by HBsAg has therefore been postulated to be responsible for the absence of anti-HBs production $[2,14]$. However, in our study $\mathrm{T}_{8}$ levels were almost all in the normal range.

The immune response of HBsAg appears to be regulated by genetic factors. Milich and Neurath and co-workers have elucidated the complex regulatory mechanisms by studying high responder and low/nonresponder mice [16-21]. After crossbreeding experiments, it was possible to identify haplotype $\mathrm{H}-2^{\mathrm{q}, \mathrm{d}}$ as high responders, haplotype $\mathrm{H}-2^{\mathrm{a}, \mathrm{b}, \mathrm{k}}$ as intermediate to low responders, and haplotype $\mathrm{H}-2^{\mathrm{s}, \mathrm{f}}$ as nonresponders. Furthermore, immune responses are governed by two immune response (Ir) genes, one in the I-A subregion (Ir-HBs-1) and one in the I-C subregion (Ir-HBs-2) of the murine $\mathrm{H}-2$ complex. Ir-HBs-1 regulates the primary responses to all HBsAg determinants, whereas the influence of Ir-HBs-2 is determinant-specific, affecting the responses to the $\mathrm{d}$ or $\mathrm{y}$ determinants.

Our results suggest evidence for an "immunogenetic background" regulating the immune response to HBsAg in man. In this study, A-10, B-12, CW-5, DR-3, and DR-5 were found to be increased in histocompatibility testing, whereas DR2 was decreased. With regard to DR-3, this is in agreement with Craven et al. [5]. Paradoxically, an increased frequency of HLA-DR-3 was also seen in patients with autoimmune chronic active hepatitis [15]. Usually, one would expect patients with autoimmune diseases to be high responders instead of low responders. Our results differ from Craven et al. [5], Cooksley et al. [4], and Walker et al. [27] with regard to DR-7, which they found elevated.

However, these authors did not correct their $P$-values according to the number of determined HLA antigens [23]. After performing this correction, the above-mentioned differences in our study no longer remained significant. Thus, our results may only be suggestive of trend differences in the frequency of HLA antigens in nonresponders to HBsAg. The different findings in various studies may indicate that most associations were due to chance. Furthermore, the conflicts between the various reports suggest that better immunogenetic markers will be necessary for a clear indication of a genetic regulatory mechanism, such as is indicated in the mouse model.

Acknowledgments. Our thanks are due to Prof. Dr. R. Thomssen, Hygiene Institut der Universität Göttingen, for providing us with the vaccine. We are also indebted to Priv-Doz. Dr. Dr. W. Hopfenmüller for support in the statistical evaluation of the data, to Mrs. A. Lottmann for technical assistance, and to Drs. R.J. Biggar, S.Z. Wiktor, and E.L. Murphy for help in preparing the manuscript, and to Ms. Mary Ann Abraham for typing it.

\section{References}

1. Armitage P (1971) Statistical methods in medical research. Blackwell, Oxford

2. Barnaba V, Levrero M, Van Dyke AD, Musca A, Cordova $C$, Balsano $F$ (1985) T-cell subsets in the hyporesponsiveness to hepatitis-B surface antigen ( $\mathrm{HBsAg}$ ) and antigenspecific suppressor lymphocytes in chronic hepatitis-B virus (HBV) infection. Clin Immunol Immunopathol 34:284 295

3. Bommer J, Deinhardt F, Jilg W, Darai D, Andrassy K, Ritz E (1983) Impfung urämischer Patienten gegen Hepatitis-B. Dtsch Med Wochenschr 108:1823-1826

4. Cooksley WGE, Hanson RG, Powell LW, Strachan N (1985) Effects of dose and HLA status on the response to hepatitis- $B$ vaccine in man (abstract). Hepatology 5:1057

5. Craven DE, Awdeh ZL, Kunches LM, Yunis EJ, Dienstag JL, Werner BG, Polk BF, Snydman DR, Platt R, Crumpacker CS, Grady GF, Alper CA (1986) Nonresponsiveness to hepatitis-B vaccine in health care workers: results of revaccination and genetic typing. Ann Intern Med $105: 356-360$

6. Dienstag JL, Werner BG, Polk BF, Syndman DR, Craven DE, Platt R, Crumpacker CS, Oullet-Hellstrom R, Grady GF (1984) Hepatitis-B vaccine in health care personnel: safety, immunogenicity, and indicators of efficacy. Ann Inter Med 101:34-40

7. Guesry PR, Adamovicz P, Jungers P, Couroucé A-M, Laplanche A, Lacour B, Benhamou E, Degos F, Crosnier J (1982) Vaccination against hepatitis-B in high-risk hemodialysis units: a double-blind study. In: Szmuness W, Alter HJ, Maynard JE (eds) Viral hepatitis. Franklin Institute Press, Philadelphia, pp 493-507

8. Hiddemann W, Ludwig WD, Hermann F, Harbott J, Beck JD, Lampert F, Odenwald E, Riehm H (1986) New techniques in the diagnosis and pretherapeutic characterization of acute leukemias in children: analyses by flow cytometry, immunology and cytogenetics in the BFM studies. Monogr Paediat 18:106-127

9. Hollinger FB, Adam E, Heiberg D, Melnick JL (1982) Response to hepatitis-B vaccine in a young adult populaton. In: Szmuness W, Alter HJ, Maynard JE (eds) Viral hepatitis. Franklin Institute Press, Philadelphia, pp 451-466

10. Jacobson IM, Jaffers G, Dienstag JL, Tolkoff-Rubin NE, Cosimi AB, Delmonico F, Watkins E, Hinkle C, O'Rourke $S$, Russell PS (1985) Immunogenicity of hepatitis-B vaccine in renal transplant recipients. Transplantation 39:393-395

11. Jilg W, Schmidt M, Zachoval R, Deinhardt F (1985) Persistenz von Antikörpern gegen Hepatitis-B-Oberflächenantigen nach Impfung gegen Hepatitis-B. Dtsch Med Wochenschr 110:205-209

12. Joint Report (1980) In: Terasaki PI (ed) Histocompatibility testing. Report of the 8th International Histocompatibility Workshop held in Los Angeles, California. UCLA Tissue Typing Laboratory, Los Angeles, 962-963 
13. Krämer A, Sommer D, Hahn EG, Riecken EO (1986) German experimental hepatitis- $B$ vaccine - influence of variation of dosage schedule, sex, and age differences on immunogenicity in health care workers. Klin Wochenschr 64:688-694

14. Lemm G, Salzer K, Warnatz H (1983) Studies on immunoregulatory mechanisms in acute and chronic hepatitis-B. Clin Exp Immunol 52:250-258

15. Mackay IR, Tart BD (1980) HLA associations with autoimmune-type chronic active hepatitis: identification of B8DRw3 haplotype by family studies. Gastroenterology 79:95-98

16. Milich DR, Chisari FV (1982) Genetic regulation of the immune response to hepatitis-B surface antigen ( $\mathrm{HBsAg}$ ): I. $\mathrm{H}-2$ restriction of the murine humoral immune response to the $a$ and $d$ determinants of HBsAg. J Immunol $129: 320-325$

17. Milich DR, Leroux-Roels GG, Chisari FV (1983) Genetic regulation of the immune response to hepatitis- $B$ surface antigen (HBsAg): II. Qualitative characteristics of the humoral immune response to the $\mathrm{a}, \mathrm{d}$ and $\mathrm{y}$ determinants of HBsAg. J Immunol 130:1395-1400

18. Milich DR, Alexander H, Chisari FV (1983) Genetic regulation of the immune response to hepatitis-B surface antigen (HBsAg): III. Circumvention of the nonresponsiveness in mice bearing HBsAg nonresponder haplotypes. I Immunol 130:1401-1407

19. Milich DR, Leroux-Roels GG, Louie RE, Chisari FV (1984) Genetic regulation of the immune response to hepatitis-B surface antigen ( $\mathrm{HBsAg})$ : IV. Distinct H-2-linked Ir genes control antibody responses to different HBsAg determinants on the same molecule and map to the I-A and I-C subregions. I Exp Med 159:41-56

20. Milich DR, Louie RE, Chisari FV (1985) Genetic regulation of the immune response to hepatitis- $B$ surface antigen (HBsAg): V. T-cell proliferative response and cellular interactions. J Immunol 134:4194-4202

21. Milich DR, Thornton GB, Neurath AR, Kent SB, Michel M-L, Tiollais P, Chisari FV (1985) Enhanced immunogeni- city of the pre-S region of hepatitis-B surface antigen. Science 228:1195-1198

22. Stevens CE, Alter HJ, Taylor PE, Zang EA, Harley EJ, Szmuness W, the Dialysis Vaccine Trial Study Group (1984) Hepatitis- $B$ vaccine in patients receiving hemodialysis: immunogenicity and efficacy. N Engl J Med 311:496-501

23. Svejgaard A, Jersild C, Staub-Nielsen W, Bodmer W-F (1974) HLA antigens and disease. Statistical and genetical considerations. Tissue Antigens 4:95-105

24. Szmuness W, Stevens CE, Harley EJ, Zang EA, Alter HJ, Taylor PE, DeVera A, Chen GTS, Kellner A, the Dialysis Vaccine Trial Study Group (1982) Hepatitis-B vaccine in medical staff of hemodialysis units: efficacy and subtype cross-protection. N Engl J Med 307:1481-1486

25. Terasaki PI, McClelland JD (1964) Microdroplet assay of human serum cytotoxins. Nature 204:998-1000

26. Van Rood JJ (1979) Microlymphocytotoxicity method. In: Ray JG (ed) Manual of tissue typing techniques. National Institutes of Health, Bethesda, pp 104-105

27. Walker ME, Szmuness W, Stevens CE, Rubinstein P (1981) Genetics of anti-HBs responsiveness: I. HLA-DR7 and nonresponsiveness to hepatitis vaccination (abstract). Transfusion 21:601

28. Wildgrube HJ, Classen M, von Lohr R, Kurth R, Brede HD (1984) Active Immunisierung gegen Virushepatitis-B. Dtsch Med Wochenschr 109:246-250

Received: February 19, 1988

Returned for revision: April 18, 1988

Accepted: May 17, 1988

Dr. Alexander Krämer

Medizinische Klinik mit Schwerpunkt Gastroenterologie

Klinikum Steglitz

Freie Universität Berlin

Hindenburgdanm 30

D-1000 Berlin 45 